\title{
Correction to: Burosumab in X-linked hypophosphatemia: a profile of its use in the USA
}

\author{
Katherine A. Lyseng-Williamson ${ }^{1}$
}

Published online: 12 November 2018

(c) Springer Nature 2018

\section{Correction to: \\ Drugs \& Therapy Perspectives (2018) 34(14):497-506 https://doi.org/10.1007/s40267-018-0560-9}

The article Burosumab in X-linked hypophosphatemia: a profile of its use in the USA, written by Katherine A. Lyseng-Williamson, was originally published Online First without open access. After publication in volume 34, issue 11, pages 497-506, Ultragenyx Pharmaceutical Inc. in partnership with Kyowa Kirin International plc requested that the article be Open Choice to make the article an open access publication. Post-publication open access was funded by Ultragenyx Pharmaceutical Inc. in partnership with Kyowa Kirin International plc. The article is forthwith distributed under the terms of the Creative Com_mons
Attribution-NonCommercial 4.0 International License (http://creativecommons.org/licenses/by-nc/4.0/), which permits any noncommercial use, duplication, adaptation, distribution and reproduction in any medium or format, as long as you give appropriate credit to the original author(s) and the source, provide a link to the Creative Commons license and indicate if changes were made.

The original article has been updated.

Open Access This article is distributed under the terms of the Creative Commons Attribution 4.0 International License (http://creativeco mmons.org/licenses/by/4.0/), which permits unrestricted use, distribution, and reproduction in any medium, provided you give appropriate credit to the original author(s) and the source, provide a link to the Creative Commons license, and indicate if changes were made.
Katherine A. Lyseng-Williamson

dtp@adis.com

1 Springer, Private Bag 65901, Mairangi Bay, 0754 Auckland, New Zealand 